\title{
BIOSOCIAL DIVERSITY OF SCOTS PINE (PINUS SYLVESTRIS L.) IN A TREE STAND IN RELATION TO CHOSEN HYDRAULIC CONDUCTIVITY INDICATORS OF THE STEM
}

\author{
Tomasz Jelonek ${ }^{1}$, Witold Pazdrowski ${ }^{1}$, Joanna Kopaczy ${ }^{1,2}$, \\ Magdalena Arasimowicz-Jelonek ${ }^{2}$, Arkadiusz Tomczak ${ }^{1}$ \\ 1Poznan University Of Life Sciences \\ Poland \\ 2Adam Mickiewicz University \\ Poland
}

(Received October 2020)

\begin{abstract}
The research focused in determining the lignification indicator of fresh needled springs and the mass of fresh needles in reference to the lignin content in tracheid walls of peripheral area of the stem (MFT/LC and MFN/LC) of Scots pine differentiated as far as its biosocial position within the community expressed by Kraft's classification. The material for the analysis came from mature pine stands growing on North European Plain, on the territory of Poland. Chemical and structural analyses of wood encompassed the area of mature sapwood, i.e. thickness of the last 10 annual rings located at $1.3 \mathrm{~m}$ (DBH). It seems that the noticed differences values of both indicators (MFT/LC and MFN/LC) in pines belonging to the first three Kraft's biological classes are connected with physiological, physical and structural conditionings of water transport with minerals in xylem and are closely connected with competition for sunlight, water, nutrients and living space.
\end{abstract}

KEYWORDS: Pinus sylvestris L., mass of fresh needles, lignin content, tracheid walls, sapwood, peripheral area of stem. 


\section{INTRODUCTION}

Xylogenesis is multistage process, which leads to the formation of xylem. Each of the stages is regulated by a network of correlations based on positive and negative influences of plant growth regulators. Among numerous tree species, phytohormones, particularly auxins and cytokinins, play a significant role in the process (Fajstavr et al. 2018). They affect certain proteins and genes, and force process, which contribute to the formation of various types of xylem, to take place (Goodwin 1978, Shininger 1979, Sudachkova et al. 2012).

Lignin, whose structure in itself is intriguing, is a significant component of lignified walls, and also above all contributes to the stiffness of cell walls. It is an organic polymer whose basic structural elements are derivatives of phenylpropane. A phenylpropane unit consists of a benzene ring composed of six carbon atoms and propane bonds composed in 3 carbon atoms (Fengel and Wegener 1989). The presence of lignin in the walls of the dead conductive cells of the xylem not only protects the wall against collapse at negative pressure while transporting water with minerals but also offers protection against embolism. Lignification of the cell wall provides a general mechanical resistance and stability of the entire plant organism, especially trees (Barnett and Jeronimidis 2003, Boerjan et al. 2003, Üner et al. 2011, Antonova et al. 2014, Kim and Daniel 2014, Tsuyama and Takabe 2014).

Lignin of deciduous trees in comparison with lignin of coniferous trees is characterised by higher percentage of content of methoxy groups and greater ratio of methoxy groups (-OCH3) to hydroxy groups (-OH) (Fengel and Wegener 1989). In wood, lignin bonds with saccharides and together create lignin-hemicellulose compounds. Chemical bonds: ester, ether, glucosidic, or acetalic (Fengel and Wegener 1989) can occur between these compounds. Furthermore, lignin limits cell wall swelling of anatomical wood elements as well as increases immunity against microorganisms (Austin and Ballaré 2010, Shmulsky and Jones 2011). It also polymerises between polysaccharide components of cell walls and appears after the cell growth or at least a part of a cell wall. Lignin is found in the intercellular layer, primary wall and secondary wall. In dead wood cells such as tracheids, impregnation of the wall with lignin secures the wall polysaccharides against partial hydrolysis (O'Brien 1970). The biosynthesis of lignin was intensively researched over the last few years (Brown 1961, Boerjan et al. 2003, Austin and Ballare 2010, Antonova et al. 2014). Phylogenetic origin of plants conditions various ratios of the three basic units in lignin, i.e. syringic alcohol, coniferyl alcohol, and p-coumaryl alcohol. Lignin which is present in cell walls of Scots pine wood consists of coniferylic units with some admixture of p-coumarylic and syringic units (de Stevens and Nord 1953). The common precursor for all derivatives of phenylpropane is shikimic acid (Tomaszewski 1964). In Scots pine, shikimic acid appears in small amounts as one of the first products of photosynthesis (Hasegawa 1962). By adding the radioactive shikimic acid to callus tissue culture of Pinus strobus, Hasegawa et at. (1960) noticed an effective incorporation of this compound into the lignin. Hasegawa (1962) achieved similar results also in reference to tracheids of the Scots pine.

Considering the role and significance of lignin in the functioning of trees and in the lignification process itself, there has been an attempt to determine the manner of shaping the quotient of mass of fresh needled springs and the mass of fresh needles to lignin content in tracheid walls of the peripheral area of the pine stem which represent first three Kraft's classes (I, II, III) which constitute the main tree stand, i.e. predominant trees (I), dominant trees (II) and co-dominant trees (III). 


\section{MATERIAL AND METHODS}

The research encompassed mature pine stands which had been growing in optimal habitat conditions for this greenwoodogenic species on North European Plain. The sample areas were located over four stands of Scots pine (Pinus sylvestris L.) which were within the limits of natural habitats for that particular species in Europe. All the research areas were located in the North of Poland, and the research itself encompassed 36 sample trees, at the ages between 89 and 91 . In each tree stand a 1-hectare sample area was established, where the measures of diameter at breast height (DBH) were taken among all pines and simultaneously they were divided into three Kraft's biosocial classes (Kraft 1884). The trees were classified into predominant, dominant and co-dominant categories. In each Kraft's biosocial class, the trees' heights were measured according to their number in the assumed $2 \mathrm{~cm}$ stages of thickness. The measurements of the sample trees were determined on the basis of their thickness class following the dendrometric method (Van Laar and Akça 2007). In each sample area 9 sample trees were selected and felled, hence a total of 36 model trees was harvested. From each sample tree, material for research, i.e. a disc-shaped sample was cut at $\mathrm{DBH}$ level $(1.3 \mathrm{~m})$. In the next step, for each of the tree, the annual volume was determined, as well as, the mass of fresh needled springs and the mass of fresh needles which was done through direct weighing process. The purpose of the disc was to ascertain the sapwood area $(\mathrm{Sa})$ and the area of earlywood in sapwood (Eas).

The material used to mark lignin in tracheid walls was collected from the last 10 thickness increments, i.e. from the sapwood which is physiologically active. The measurements of the sapwood area $(\mathrm{Sa})$ and the area of earlywood was conducted by using increment borer Preisser Digi-Met and a computer programme "Grube Comm". In the sapwood area, the width of earlywood in each annual ring was measured. The areas of earlywood in the peripheral area of the stem (sapwood) was determined as the total area of all annual rings. In addition, the data concerning the mass of fresh needles (Nmass) from sample tress and sapwood area $(\mathrm{Sa})$ as well as the area of earlywood in sapwood zone (Eas) was used to determine a relative efficiency of conductive surface of the analysed tree samples. This was achieved by dividing sapwood area and the area of earlywood tracheids in the cross-sectional area of the trunk by the mass of fresh needles (Eqs. 1 and 2):

$$
\begin{aligned}
& \mathrm{S}_{\mathrm{a}} / \mathrm{N}_{\text {mass }}\left(\mathrm{mm}^{2} \mathrm{~kg}^{-1}\right) \\
& \mathrm{E}_{\mathrm{as}} / \mathrm{N}_{\text {mass }}\left(\mathrm{mm}^{2} \cdot \mathrm{kg}^{-1}\right)
\end{aligned}
$$

The lignin content $L c\left(\mathrm{mg}^{*} \mathrm{~g}^{-1}\right)$ of dry mass) was marked spectrophotometrically (in three repetitions) following Doster's method (1988). At the first, the wood of the last 10 annual rings was treated with methanol for 48 hours, the adopted ratio was $1 \mathrm{ml}$ of methanol per $1 \mathrm{~g}$ of xylem, and next it underwent the drying process. From each variant, i.e. Kraft's class, $20 \mathrm{mg}$ of dry xylem was collected and was mixed with $5 \mathrm{ml}$ of $2 \mathrm{~N} \mathrm{HCL}$ and $0.5 \mathrm{ml}$ of thioglycolic acid (Sigma-Aldrich). The samples underwent incubation at the temperature of $95^{\circ} \mathrm{C}$ for over 4 hours, next they were centrifuged at $3000 \mathrm{~g}$ for $20 \mathrm{~min}$. The achieved precipitate was washed with deionised water and incubated with $5 \mathrm{ml} 0.5 \mathrm{~N} \mathrm{NaOH}$ over 18 hours in room temperature. After centrifuging at $15000 \mathrm{~g}, \mathrm{NaOH}$ extraction was collected, and the precipitation was washed with $4 \mathrm{ml}$ of deionised water and centrifuged once more. The obtained supernatant was mixed with $\mathrm{NaOH}$ extraction, $1 \mathrm{ml}$ of concentrated $\mathrm{HCL}$ was acidified and left overnight at $5^{\circ} \mathrm{C}$. The obtained precipitation after centrifuging (15000 g) was dissolved in $5 \mathrm{ml} 0.5 \mathrm{~N} \mathrm{NaOH}$, 
it was centrifuged $(15000 \mathrm{~g})$ and the absorbance of the solution was measured at the wavelength of $380 \mathrm{~nm}$ using the UV-1202 Shimadzu spectrophotometer. The lignin content was expressed in relative units of absorbance. With the data concerning the mass of fresh needled springs, mass of fresh needles and lignin content in tracheid walls from last ten annual increment thickness from the peripheral area of trunks of chosen pines, it was possible to calculate the quotient of fresh needled springs mass divided by lignin content in tracheid walls as well as the quotient of fresh needles mass to the lignin content in tracheid walls in the last ten annual rings.

The research also determined the mean volume increase of the analysed standing trees by adopting volume tables, prepared in 1908. Moreover, the basic statistical characteristics of the analysed variables and correlations between them were established. The obtained empirical material was analysed by adopting the methods of mathematical statistics by using Statistica 13.0 statistical kit.

\section{RESULTS AND DISCUSSION}

The manner of shaping the measures of location and spread of relative conductivity surface $\left(\mathrm{S}_{\mathrm{a}} / \mathrm{N}_{\text {mass }}\right.$ and $\mathrm{E}_{\mathrm{as}} / \mathrm{N}_{\text {mass }}$ ) of pine which represent different biosocial classes were depicted in Tab. 1.

Tab. 1: The characteristics of hydraulic conductivity indicators $\left(S_{d} / N_{\text {mass }}, E_{a s} / N_{\text {mass }}\right)$ of Scots pine (Pinus sylvestris L.) depending on the biosocial position of the tree in the tree stand.

\begin{tabular}{|c|c|c|c|c|c|}
\hline \multicolumn{6}{|c|}{$\mathrm{S}_{\mathrm{a}} / \operatorname{Nmass}\left(\mathrm{mm}^{2 \cdot} \mathrm{kg}^{-1}\right)$} \\
\hline Kraft's class & Mean & STD & Min & Max & $\mathrm{CV}$ \\
\hline & & & & & (\%) \\
\hline $\mathrm{I}$ & 1297.48 & 295.51 & 736.97 & 1668.37 & 22.78 \\
\hline II & 1212.64 & 428.23 & 486.17 & 1983.84 & 35.31 \\
\hline III & $1657.67^{*}$ & 668,06 & 751.71 & 3335.65 & 40.30 \\
\hline Total & 1389.26 & 513.45 & 486.17 & 3335.65 & 36.96 \\
\hline \multicolumn{6}{|c|}{$\mathrm{E}_{\mathrm{as}} / \mathrm{N}_{\text {mass }}\left(\mathrm{mm}^{2} \cdot \mathrm{kg}^{-1}\right)$} \\
\hline Kraft's class & Mean & STD & Min & Max & $\mathrm{CV}$ \\
\hline & & & & & (\%) \\
\hline $\mathrm{I}$ & 767.26 & 160.81 & 510.06 & 995.92 & 20.96 \\
\hline II & 750.26 & 295.70 & 294.43 & 1327.79 & 39.41 \\
\hline III & $1015.56^{*}$ & 437.30 & 497.33 & 2246.90 & 43.06 \\
\hline Total & 844.36 & 332.92 & 294.43 & 2246.90 & 39.43 \\
\hline
\end{tabular}

"Statistically significant differences at the level of $p<0.05$.

The relative area of hydraulic conductivity of the stem was expressed by the quotient of sapwood area $\left(S_{a}\right)$ divided by the fresh needles mass $\left(N_{\text {mass }}\right)$ and the quotient of the earlywood area in sapwood divided by the fresh needles mass $\left(N_{\text {mass }}\right)$; it was diversified depending on the biosocial position of the tree in the tree stand. In both cases the relative area of hydraulic conductivity of the stem $\left(S_{a} / N_{\text {mass }}\right.$ and $\left.E_{s a} / N_{\text {mass }}\right)$ in pines which represent the third Kraft's biosocial class, which was statistically significant higher $(\mathrm{p}<0.05)$ in comparison to predominant and dominant pines (Tab. 1). The mean of both indicators in the case of co-dominating pines (III Kraft's class) were respectively $1657.67\left(\mathrm{~mm}^{2} \cdot \mathrm{kg}^{-1}\right)\left(S_{a} / N_{\text {mass }}\right)$ and $115.36\left(\mathrm{~mm}^{2} \cdot \mathrm{kg}^{-1}\right)$ $\left(E_{s a} / N_{\text {mass }}\right)$; however, in predominant trees it was $1297.48\left(\mathrm{~mm}^{2} \cdot \mathrm{kg}-1\right)\left(S_{a} / N_{\text {mass }}\right)$ and $767.26\left(\mathrm{~mm}^{2} \cdot \mathrm{kg}^{-1}\right)\left(E_{\text {sa }} / N_{\text {mass }}\right)$ and in dominant pines $1212.64\left(\mathrm{~mm}^{2} \cdot \mathrm{kg}^{-1}\right)\left(S_{a} / N_{\text {mass }}\right)$ 
Vol. $66(3): 2021$

and $750.26\left(\mathrm{~mm}^{2} \cdot \mathrm{kg}^{-1}\right)\left(E_{s a} / N_{\text {mass }}\right)$. The lowest variability of the $S_{a} / N_{\text {mass }}$ indicator was noticed in pines from Kraft's I class (22.78\%) and the highest in tress from Kraft's II class (tab. 1). In the case of the case of the indicator $\left(E_{s a} / N_{\text {mass }}\right)$ the lowest coefficient of variability was among predominant trees and the highest was among dominant pines (Tab. 1).

Tab. 2: Statistical characteristics of $M F T / L C$ and $M F N / L C$ coefficients in Scots pine (Pinus sylvestris L.) depending on the biosocial position of the tree in the tree stand.

\begin{tabular}{|c|c|c|c|c|c|}
\hline \multicolumn{6}{|c|}{ MFT/LC $\left(\mathrm{g} \cdot\left(\mathrm{mg} \cdot \mathrm{g}^{-1}\right)^{-1}\right)$} \\
\hline Kraft's class & Mean & STD & Min & Max & $\begin{array}{l}\text { CV } \\
\text { (\%) }\end{array}$ \\
\hline $\bar{I}$ & 226.43* & 65.50 & 122.16 & 327.83 & 28.93 \\
\hline II & $158.95^{*}$ & 48.64 & 96.16 & 253.70 & 30.60 \\
\hline III & $99.64^{*}$ & 36.18 & 52.73 & 165.16 & 36.31 \\
\hline Total & 161.67 & 72.54 & 52.73 & 327.83 & 44.87 \\
\hline \multicolumn{6}{|c|}{ MFN/LC $\left(\mathrm{g} \cdot\left(\mathrm{mg} \cdot \mathrm{g}^{-1}\right)^{-1}\right)$} \\
\hline Kraft's class & Mean & STD & Min & Max & $\begin{array}{l}\mathrm{CV} \\
(\%)\end{array}$ \\
\hline $\bar{I}$ & $147.95^{*}$ & 40.97 & 83.11 & 208.46 & 27.69 \\
\hline II & $102.33^{*}$ & 26.55 & 63.49 & 146.35 & 25.95 \\
\hline III & $67.73^{*}$ & 23.41 & 37.92 & 109.34 & 34.56 \\
\hline Total & 106.00 & 45.07 & 37.92 & 208.46 & 42.52 \\
\hline
\end{tabular}

Statistically significant differences at the level of $p<0.05$.

Statistical characteristics of the quotient of fresh moisture springs mass divided by lignin content in tracheid walls in the peripheral area (MFT/LC) and the quotient of fresh needles mass divided by the lignin content in tracheid walls of the peripheral area of the stem (MFN/LC) was presented in Tab. 2. The lowest mean value $\left.\left(226.43 \mathrm{~g} \cdot\left(\mathrm{mg}^{\cdot} \mathrm{g}^{-1}\right)^{-1}\right)\right)$ of the indicator (MFT/LC) was noticed in predominant trees representing I Kraft's class, lower (158.95) in pines from II Kraft's class, and the lowest $\left.\left(99.64 \mathrm{~g} \cdot\left(\mathrm{mg} \cdot \mathrm{g}^{-1}\right)^{-1}\right)\right)$ in co-dominant pines (Tab. 2). The variable expressed by the coefficient of variability in the case of (MFT/LC) and the lowest value was noticed in predominant trees (28.93\%), in dominant pines $(30.60 \%)$ and in co-dominant trees (36.31\%) (Tab. 2). As far as the quotient of fresh needles mass divided by the lignin content in tracheid wall of ten annual rings of the peripheral area of the stem in concerned, the highest value of the indicator (MFN/LC) was observed in pines from I Kraft's class $\left(147.95 \mathrm{~g} \cdot\left(\mathrm{mg}^{-} \mathrm{g}^{-1}\right)^{-1}\right)$, lower $\left(102.33 \mathrm{~g} \cdot\left(\mathrm{mg} \cdot \mathrm{g}^{-1}\right)^{-1}\right)$ in trees from II class whereas the lowest $\left.\left(67.73 \mathrm{~g} \cdot\left(\mathrm{mg}^{\circ} \mathrm{g}^{-1}\right)^{-1}\right)\right)$ in co-dominant pines (Tab. 2). The standard variation ranged between $23.40 \mathrm{~g} \cdot\left(\mathrm{mg} \cdot \mathrm{g}^{-1}\right)^{-1}$ to $40.97 \mathrm{~g} \cdot\left(\mathrm{mg} \cdot \mathrm{g}^{-1}\right)^{-1}$ (Tab. 2). The coefficient of variability of the described indicators was in the range $25.94 \%$ to $34.55 \%$ (Tab. 2). The statistical characteristics of the mean increase of the volume in pine trunks which represent the main tree stand, i.e. predominant trees, dominant trees and co-dominant trees have been collected and presented in Tab. 3. The highest value of mean increase of tree volume was noticed in trees from I Kraft's class (predominant trees); however, as the biosocial position progressively deteriorates in the tree stand, the value of mean increment of trees clearly lowers (Tab. 3). The standard deviation and coefficient of variability have also indicated this regularity (Tab. 3). The standard ranged from 0.0009 to 0.0025 whereas the coefficient of variability was from $19.40 \%$ to $25.25 \%$.

Tab. 3: Statistical characteristics of the mean increment of the pine stems in each Kraft's biosocial class.

\begin{tabular}{llllll}
\hline Kraft's class & Mean & STD & Min & Max & $\begin{array}{l}\text { CV } \\
(\%)\end{array}$ \\
\hline
\end{tabular}




\begin{tabular}{llllll}
\hline I & & & & \\
II & $0.0098^{*}$ & 0.0025 & 0.0057 & 0.0136 & 25.25 \\
III & $0.0069^{*}$ & 0.0015 & 0.0047 & 0.0089 & 21.58 \\
\hline Total & $0.0048^{*}$ & 0.0009 & 0.0033 & 0.0065 & 19.40 \\
\hline * Statistically significant differences at the lovel $p<0.05$. & 0.0027 & 0.0033 & 0.0136 & $37.72^{*}$ \\
\hline
\end{tabular}

${ }^{*}$ Statistically significant differences at the level of $p<0.05$.

On the basis of the conducted statistical analyses, it was observed that there is a clear relationship between hydraulic conductivity indicators $\left(S_{a} / N_{\text {mass }}\right.$ and $\left.E_{a s} / N_{\text {mass }}\right)$ and the quotient of the mass of fresh needled springs divided by the lignin content in tracheid walls of the peripheral area of the stem (MFT/LC), and the quotient of the fresh needles mass divided by the lignin content in the tracheid walls in the peripheral area (MFN/LC) and the annual increase of stem volume of the trees from the main tree stand. The mean volume increase is a dependent variable whereas the hydraulic conductivity indicators $\left(S_{a} / N_{\text {mass }}\right.$ and $\left.E_{s a} / N_{\text {mass }}\right)$ and (MFT/LC and MFN/LC) indicators are independent variables.

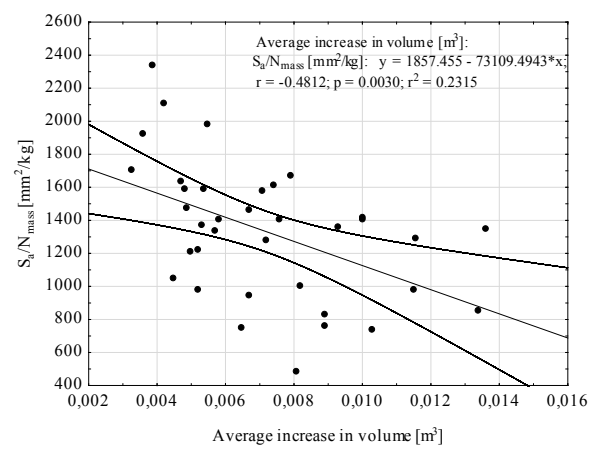

Fig. 1: The mean increase in volume of pine stems in reference to bydraulic conductivity indicator expressed by the quotient $S_{a} / N$ mass.

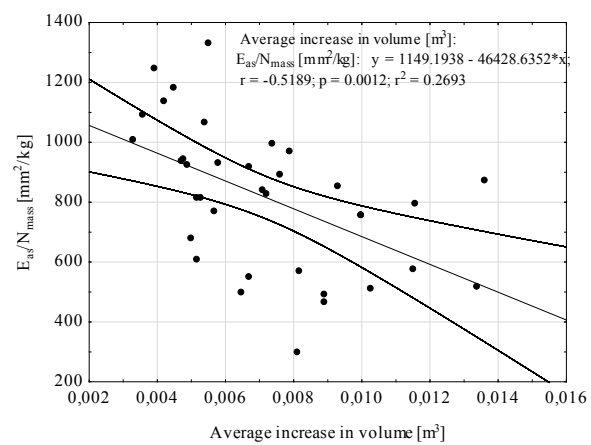

Fig. 2: The mean increase in volume of pine stems in reference to hydraulic conductivity indicator expressed by the quotient $E_{\text {as }} / N$ mass.

The mean increase in volume of the pine stems from the sapwood area which referred to the mass of fresh needles $\left(S_{a} / N_{\text {mass }}\right)$ correlated negatively. The correlation coefficient assumed the values on the significance level $\mathrm{p}<0.05$ value $\mathrm{r}=-0.4812$ (Fig 1 ). The earlywood area in sapwood was referred to the mass of fresh needles $\left(E_{a s} / N_{\text {mass }}\right)$, and it also assumed values on the level of significance $\mathrm{p}<0.05$ and correlated negatively, and the value of correlation coefficient was $r=-0,5189$ (Fig. 2). The mean increase in volume of pine wood in the main tree stand was conditioned significantly by the MFT/LC and MFN/LC coefficients; as a result, the calculated correlation coefficients were $r=+0.94852$ in the first one and $r=+0.95083$ in the second case (Figs. 3 and 4).

\section{Discussion}

In the introduction it was mentioned that xylogenesis is a multistage transformation process which eventually leads to the formation of secondary xylem. Each of the stages is regulated by a network of interdependencies based on positive, or negative, interactions with growth regulators (Fajstavr et al. 2018). Among the entire range of regulators, phytohormones, especially auxins and cytokinins, play a significant role in growth and development processes of plants, including trees. The influence of some proteins and genes by coercing particular transformations to take 
place, which in the end leads to formation of (Little and Pharis 1995). Xylem is optimised to various degrees as far as their functions are concerned, such as tree growth conditions and strategies allowing its survival. As a result, the characteristic features of the formed xylem are, among others, a complex chemical composition and anatomical structure which is characteristic for each tree species, from which the physical and mechanical properties of wood as a material, including building and construction material, directly results (Barnett and Jeronimidis 2003, Jelonek et al. 2012). Even within a single species there can be differences in structure and properties of xylem, for instance resulting from the geographical location (Martínez-Vilalta 2009, Fernandes et al. 2016), habitat conditions (Eilmann et al. 2011, Matisons et al. 2019), age or biosocial position within in the stand (Pazdrowski et al. 1993, Nilsson and Albrektson 1993, Mäkinen 1996, Vanninen and Mäkelä 2000, Eriksson 2006). The growth and increase of tree species are determined, to a great extent, by the size of their crown, which provides information about the size of the transpiration and assimilation apparatus. The mass of leaves or needles, including the participation of the lighted and shaded crown, intensiveness of the assimilation process, fertility of the habitat and access to water rich in minerals determine xylem production. The amount of biomass collected in various tissues, organs or tree components is known as allocation (Litton et al. 2007). It is usually expressed mathematically as a share of the biomass of a given faction (Poorter and Sack 2012, Poorter et al. 2012) or as a ratio of biomass of various components, i.e. above-ground biomass to underground biomass (Poorter and Sack 2012). In Franklin et al. (2012) the five basic theories explaining the biomass allocation process have been distinguished. In forestry, allometric model is widely used, which assumes that the absolute size of the biomass of a single organ is a dimension function of a different one and the relationship is described by power function (Gayon 2000). However, it should be emphasised that allometric relationships do not consider the influence of internal and environmental factors on the biomass allocation including dendromass, which is significantly conditioned by the tree growth factors (Kellomäki 1981, Oleksyn et al. 1999, Poorter et al. 2012).

The article attempts to analyse the process of establishing the relationship between the mass of fresh needled springs to the lignin content in the tracheid walls in the last ten annual increment thickness rings of the peripheral area of the stem of mature Scots pine (P. sylvestris L.) and the relationship of mass of fresh needles to lignin content in tracheid walls of the peripheral area of trees of various biosocial position in the tree stand. The volume mass flow of water with minerals takes place through conducting elements of the xylem from the roots to the transpiration and assimilation apparatus, the so-called long-distance transport. Moreover, the short-distance transport, inner water evaporation and transpiration takes place from higher water potential to lower water potential. The long-distance transport of water in xylem, which is against gravitation, results from the under pressure created by transpiration and also from overpressure generated by root pressure supported by cohesion and adhesion as well as capillary action (Steudle 2001).

The growth and tree increment, including wood production, are determined by preserving the equilibrium between the conducing surface of the stem and the surface of transpiration and the assimilation apparatus in specific (optimal) habitat conditions. The issue, in the work, was expressed by hydraulic conductivity indicator which was expressed by the quotient of the sapwood area and the earlywood tracheid area in sapwood divided by the mass of fresh needles of pines $S_{a} / N_{\text {mass }}\left(\mathrm{mm}^{2} \cdot \mathrm{kg}^{-1}\right), \mathrm{E}_{\mathrm{as}} / \mathrm{N}_{\text {mass }}\left(\mathrm{mm}^{2} \cdot \mathrm{kg}^{-1}\right)$ representing the main tree stand (predominant, dominant and co-dominant trees).

The obtained results indicate a clear differentiation of the relative conductive area Sa / $N$ mass $\left(\mathrm{mm}^{2} \cdot \mathrm{kg}^{-1} \mathrm{E}_{\mathrm{as}} / \mathrm{N}_{\text {mass }}\left(\mathrm{mm}^{2} \cdot \mathrm{kg}^{-1} \mathrm{in}\right.\right.$ Scots pine (P. sylvestris L.) depending from 
their biosocial position in the stand. The trees representing Kraft's III class (co-dominant) in both cases indicated the highest value of analysed indicators, however pre-dominating pines (Kraft's I class) and dominating ones (Kraft's II class) had definitely lower values. It means that in the trees from Kraft's III class, for $1 \mathrm{~kg}$ of fresh needles falls unequivocally the largest conducive area of sapwood $\left(1491.00 \mathrm{~mm}^{2}\right)$ and the conducive area of tracheid in earlywood in sapwood $\left(932,22 \mathrm{~mm}^{2}\right)$ than in predominating and dominating pines. In the former ones, the values of the discussed indicators were respectively $\left(1297.48 \mathrm{~mm}^{2}\right)$ and $\left(767.26 \mathrm{~mm}^{2}\right)$ and in the latter ones $\left(1212.64 \mathrm{~mm}^{2}\right)$ and $\left(750.26 \mathrm{~mm}^{2}\right)$. The matter can be explained with Pipe Model Theory as described by Shinozaki et al. (1964a,b), which holds that in a physiologically healthy tree the optimisation of the xylem's conductive surface is closely correlated with the size and efficiency of the assimilation and transpiration apparatus of the tree, as well as its height (Jelonek et al. 2008). Analysing the quotient values of the mass of fresh needled springs divided by the lignin content in tracheid wall of the peripheral area of the stem (MFT/LC) and the quotient value of mass of fresh needled divided by the lignin content in tracheid walls of the peripheral area (MFN/LC), clearly reveals the differentiation of values in both indicators in pines belonging to the first Kraft's biosocial class. The predominating trees (Kraft's I class) in the case of both indicators showed their highest value, which was MFT/LC $-226.43 \mathrm{~g} \cdot\left(\mathrm{mg} \cdot \mathrm{g}^{-1}\right)^{-1}$ and MFN/LC - $147.95 \mathrm{~g} \cdot\left(\mathrm{mg} \cdot \mathrm{g}^{-1}\right)^{-1}$; whereas the values for dominating pines (Kraft's II class) and co-dominating (Kraft's III class) were definitely lower. In the former, the values of the discussed indicators were respectively $\left(158.95 \mathrm{~g} \cdot\left(\mathrm{mg}^{\cdot} \mathrm{g}^{-1}\right)^{-1}\right.$ and $\left.102.33 \mathrm{~g} \cdot\left(\mathrm{mg}^{\cdot} \mathrm{g}^{-1}\right)^{-1}\right)$; whereas in the latter class it was $99.64 \mathrm{~g} \cdot\left(\mathrm{mg} \cdot \mathrm{g}^{-1}\right)^{-1}$ and $67.73 \mathrm{~g} \cdot\left(\mathrm{mg} \cdot \mathrm{g}^{-1}\right)^{-1}$.

The social differentiation of the trees in the tree stand is a result of competition for light and living space. The instances of greenwoodogenic species, including pines, occupy a lower position within the altitudinal structure of a tree stand, hence they suffer more from the lack of sunlight, water and also nutrients. The direct result of the struggle for environment resources is the diversification of tree sizes and the changes in xylem structures, conducting surface in xylem and phloem and also the changes in the tree crown (Mátyás and Varga 2000, Sowiński and Szczepaniak 2015). Mäkinen (1996) has noticed that the spring and needle biomass of Scots pine (P. sylvestris L.) decreases with the increase of competition.

A special attention should be paid to the relation between the hydraulic conductive indicator $\left(S_{a} / N_{\text {mass }}\right.$ and $\left.E_{s a} / N_{\text {mass }}\right)$, and the mean increase in tree cubic volume and the quotient of the mass of fresh needled springs divided by the lignin content in the tracheid walls of peripheral areas of the stem (MFT/LC) and the quotient of mass of fresh needles divided by the lignin content in tracheid walls of peripheral areas of the stem (MFN/LC), and the mean increase in tree volume. In the case of the relative conductive surface, i.e. hydraulic conductivity of stems $\left(S_{a} / N_{\text {mass }}\right.$ and $\left.E_{a s} / N_{\text {mass }}\right)$, the increase in volume correlates negatively in both cases. The value of the calculated correlation coefficients was respectively -0.4812 and -0.5189 . However, the MFT/LC and MFN/LC coefficients correlated positively but in the case of the latter the coefficient was +0.9485 and in the case of the former +0.9508 . The upturn in hydraulic conductivity indicator's value $\mathrm{S}_{\mathrm{a}} / \mathrm{N}_{\text {mass }}$ and $\mathrm{E}_{\mathrm{as}} / \mathrm{N}_{\text {mass }}$ in pines will result in lowering the mean tree volume increase; however, lowering the value of relative conducting area will result in the mean volume increase. In the case of MFT/LC and MFN/LC coefficients, together with their increase in the value, also there was a significant increase in mean volume of pines from the main tree stand, i.e. predominating trees, dominating trees and co-dominating trees.

It seems that the variation in both indictors (MFT/LC and MFN/LC) in pines representing the main tree stand is connected with physiological, physical and structural conditioning of transporting water and minerals in the stem. The trees from Kraft's I class indicated the highest 
values of the analysed indicators (MFT/LC anc MFN/LC), whose mean value was respectively $226.43 \mathrm{~g} \cdot\left(\mathrm{mg} \cdot \mathrm{g}^{-1}\right)^{-1}$ and $147.95 \mathrm{~g} \cdot\left(\mathrm{mg}^{-1} \mathrm{~g}^{-1}\right)^{-1}$. Ir pines from Kraft's II class the mean values in both indicators were lower from predomi rating trees and was $158.95 \mathrm{~g} \cdot\left(\mathrm{mg}^{-1} \mathrm{~g}^{-1}\right)^{-1}$ and $102.33 \mathrm{~g} \cdot\left(\mathrm{mg} \cdot \mathrm{g}^{-1}\right)^{-1}$; whereas in co-dominart individuals it was $99.64 \mathrm{~g} \cdot\left(\mathrm{mg}^{\circ} \mathrm{g}^{-1}\right)^{-1}$ and $67.73 \mathrm{~g} \cdot\left(\mathrm{mg}^{-1} \mathrm{~g}^{-1}\right)^{-1}$. It can be assumed that this $\mathrm{i}$; a result of a significant variability of the mass of fresh needled springs, mass of fresh needles, li z̧nin content in tracheid walls of peripheral areas of the pine stems belonging to different biosocial cla sses in the tree stand. Moreover, it would seem that the noticed values of both indicators are $c$ djusted to the intensity of the assimilation and transpiration process which may result in diversified efficiency of transporting water with minerals. The pines which occupy lower positions in the altitude structure of the tree stand are considerably more vulnerable to sunl: ght, water and nutrients deficiency rather than the trees from higher biosocial positions. The direct effect of the struggle over environmental resources is the diversification of tree sizes and changes in crown structure (Mátyás and Varga 2000). Mäkinen (1996) noticed that the bionlass of springs and needles of the Scots pine lowers with the increase of competition. Naidı. et al. (1998) researched allocation of biomass in Pinus taeda tree stands and indicated that $\mathrm{n}$ intermediate trees the share of the biomass of the stem $(75.9 \%)$ of the total tree biomass is higher in comparison to dominating trees $(63,4 \%)$. Furthermore, the intermediate pines are characterised by a higher ratio of biomass of heterotrophic parts, i.e. roots, stem and spring , than the autotrophic parts (needles). According to research conducted by Kellomäki (1981) cor cerning the influence of the available sunlight on the structure of the current increment of $S$ :ots pine, it appears that with greater access to sunlight there is a considerable shift of the current increment of biomass to the springs at the expanse of the stem and needles. The gr zatest part of the annual production of biomass reaches the stems of trees which grows in conditions with a moderate access to sunlight, but the trees growing is shade direct their greater part of the increment in assimilation apparatus. Vanninen and Mäkelä (2000), as well as Vanninen (2004) have noticed that in pine tree stands, the intermediate trees most part of their current increment locate in stem biomass in comparison to dominating trees.

\section{CONCLUSIONS}

(1) On the basis of conducted research of shaping the quotient of the mass of fresh needled springs, mass of fresh needles divided by the lignin content in tracheid wall of the peripheral area of stem (MFT/LC and MFN/LC) of Scots pine (Pinus sylvestris L.) varied as far as the biosocial positioning in the tree stand are concerned, diversification of values of analysed indicators in reference to biosocial class of the tress was observed. (2) The predominating tress possessed both indicators (MFT/LC and MFN/LC) which were considerably higher, and whose mean value was respectively $226.43 \mathrm{~g} \cdot\left(\mathrm{mg}^{-1} \mathrm{~g}^{-1}\right)^{-1}$ and $147.95 \mathrm{~g} \cdot\left(\mathrm{mg}^{\circ} \mathrm{g}^{-1}\right)^{-1}$ than pines representing II and III Kraft's biological class. Both values of the discussed indicators in dominating trees was $158.95 \mathrm{~g} \cdot\left(\mathrm{mg}^{\circ} \mathrm{g}^{-1}\right)^{-1}$ and $102.33 \mathrm{~g} \cdot\left(\mathrm{mg}^{-1} \mathrm{~g}^{-1}\right)^{-1}$, whereas in co-dominating pines it was $99.64 \mathrm{~g} \cdot\left(\mathrm{mg} \cdot \mathrm{g}^{-1}\right)^{-1}$ and $67.73 \mathrm{~g} \cdot\left(\mathrm{mg}^{\circ} \mathrm{g}^{-1}\right)^{-1}$. (3) The noticed differences in the values in both analysed indicators (MFT/LC and MFN/LC) in pines belonging to the first three Kraft's biosocial classes constituting the main tree stand are connected with physiological, physical and structural conditioning of transporting water with minerals in the xylem and are closely related with competition for sunlight, water, nutrients and living space. 


\section{REFERENCES}

1. Abreu, H.D.S., Do Nascimento, A.M., Maria, M.A., 1999: Lignin structure and wood properties. Wood and Fiber Science 31: 426-433.

2. Antonova, G.F., Varaksina, T.N., Zheleznichenko, T.V., Stasova, V.V., 2014: Lignin deposition during earlywood and latewood formation in Scots pine stems. Wood Science and Technology 48(5): 919-936.

3. Austin, A.T., Ballaré, C.L., 2010: Dual role of lignin in plant litter decomposition in terrestrial ecosystems. PNAS 107(10): 4618-4622.

4. Barnett, J.R., Jeronimidis, G., 2003: Wood quality and its biological basis. Wiley-Blackwell, $226 \mathrm{pp}$.

5. Boerjan, W., Ralph, J., Baucher, M., 2003: Lignin biosynthesis. Annual Review of Plant Biology 54(1): 519-546.

6. Boudet, A.M., Lapierre, C., Grima-Pettenati, J., 1995: Biochemistry and molecular biology of lignification. New Phytologist 129(2): 203-236.

7. Brown, S.A., 1961: Chemistry of lignification. Science 134(3475): 305-313.

8. de Stevens, G., Nord, F.F., 1953: Investigations on lignin and lignification XII. A study of lignin formation based on the oxidation of native and enzymatically liberated lignins. PNAS 39: 80-85.

9. Doster, M.A., Bostock, R.M., 1988: Quantification of lignin formation in almond bark in response to wounding and infection by Phytophtora species. Phytopathology 78: 473-477.

10. Eilmann, B., Zweifel, R., Buchmann, N., Graf Pannatier, E., Rigling, A., 2011: Drought alters timing, quantity, and quality of wood formation in Scots pine. Journal of Experimental Botany 62(8): 2763-2771.

11. Eriksson, E., 2006: Thinning operations and their impact on biomass production in stands of Norway spruce and Scots pine. Biomass and Bioenergy 30(10): 848-854.

12. Fajstavr, M., Paschová, Z., Giaglim K., Vavrčík, H., Gryc, V., Urban,J., 2018: Auxin (IAA) and soluble carbohydrate seasonal dynamics monitored during xylogenesis and phloemogenesis in Scots pine. IFOREST 11(5): 553-562.

13. Fengel, D., Wegener, G., 1989: Wood - chemistry, ultrastructure, reactions. Walter de Gruyter. Pp 132-181, Berlin, Germany.

14. Fernandes, C., Gaspar, M.J., Pires, J., Silva, M.E., Carvalho, A., Brito, J.L., Lousada, J.L., 2016: Within and between-tree variation of wood density components in Pinus sylvestris at five sites in Portugal. European Journal of Wood and Wood Products 75(4): 511-526.

15. Franklin, O., Johansson, J., Dewar, R.C., Dieckmann, U., McMurtrie, R.E., Brännström, Å., Dybzinski, R., 2012: Modeling carbon allocation in trees: a search for principles. Tree Physiology 32(6): 648- 666.

16. Gayon, J., 2000: History of the concept of allometry. American Zoologist 40(5): 748-758.

17. Goodwin, P.B., 1978: Phytohormones and growth and development of organs of the vegetative plant. In: The biochemistry od phytohormones and related compounds: a comprehensive treatise, v.2 (ed. Letham DS, Goodwin PB, Higgins TV). Pp 31-174, Elsevier/ North Holland biomedical press. Amsterdam.

18. Hasegawa, M., Higuchi, T., Ishikawa, H., 1960: Formation of lignin in tissue culture of Pinus strobus. Plant and Cell Physiology 1: 173-182.

19. Hasegawa, M., 1962: Alicyclic precursors of polyphenols. In: Wood Extractives and their Significance to the Pulp and Paper Industries (ed. Hillis WE). Pp 263-276, Elsevier. New York, NY.

20. Hatfield, R., Vermerris, W., 2001: Lignin formation in plants. The dilemma of linkage Specificity. Plant Physiology 126(4): 1351-1357. 
21. Jelonek, T., Pazdrowski, W., Tomczak, A., Grzywiński, W., 2012: Biomechanical stability of pines growing on former farmland in northern Poland. Wood Research 57(1): 31-44.

22. Jelonek, T., Pazdrowski, W., Tomczak, A., 2008: Biometric traits of wood and quality of timber produced in former farmland. Baltic Forestry 14 (2): 138-148.

23. Kellomäki, S., 1981: Effect of the within-stand light conditions on the share of stem, branch and needle growth in a twenty-year-old Scots pine stand. Silva Fennica 15(2): 130-139.

24. Kim, J.S., Daniel, G., 2014: Distributional variation of lignin and non-cellulosic polysaccharide epitopes in different pit membranes of Scots pine and Norway spruce seedlings. IAWA Journal 35(4): 407-429.

25. Kraft, G., 1884: Beiträge zur Lehre von den Durchforstungen, Schlagstellungen und Lichtungshieben. Pp 85-130, Klindworth, Hannover.

26. Little, C.H.A., Pharis, R.P., 1995: Hormonal control of radial and longitudinal growth in the tree stem. In: Plant stems physiology and functional morphology (ed. Gartner BL). Pp 281-319, Academic Press. San Diego, CA.

27. Litton, C.M., Raich, J.W., Ryan, M.G., 2007: Carbon allocation in forest ecosystems. Global Change Biology 13: 2089-2109.

28. Mäkinen, H., 1996: Effect of inter tree competition on biomass production of Pinus sylvestris (L.) half-sib-families. Forest Ecology and Management 86(1): 105-112.

29. Martínez-Vilalta, J., Cochard, H., Mencuccini, M., Sterck, F., Herrero, A., Korhonen, J.F.J., Llorens, P., Nikinmaa, E., Nolè, A., Poyatos, R., Ripullone, F., Sass-Klaassen, U., Zweifel, R., 2009: Hydraulic adjustment of Scots pine across Europe. New Phytologist 184(2): 353-364.

30. Matisons, R., Krišāns, O., Kārkliṇa, A., Adamovičs, A., Jansons, Ā., Gärtner, H., 2019: Plasticity and climatic sensitivity of wood anatomy contribute to performance of eastern Baltic provenances of Scots pine. Forest Ecology and Management 452: 117568.

31. Mátyás, C., Varga, G., 2000: Effect of intra-specific competition on tree architecture and aboveground dry matter allocation in Scots pine. Investigacion Agraria - Sistemas y Recursos Forestales. Fuera de Serie 1: 111-119.

32. Naidu, S.L., DeLucia, E.H., Thomas, R.B., 1998: Contrasting patterns of biomass allocation in dominant and suppressed loblolly pine. Canadian Journal of Forest Research 28(8): $1116-1124$.

33. Nilsson, U., Albrektson, A., 1993: Productivity of needles and allocation of growth in young Scots pine trees of different competitive status. Forest Ecology and Management 62(1-4): 173-187.

34. O'Brien, T.P., 1970: Further observations on hydrolysis of the cell wall in the xylem. Protoplasma 69(1): 1-14.

35. Oleksyn, J., Reich, P.B., Chałupka, W., Tjoelker, M.G., 1999: Differential above- and belowground biomass accumulation of European Pinus sylvestris populations in a 12-year-old provenance experiment. Scandinavian Journal of Forest Research 14(1): 7-17

36. Pazdrowski, W., Spława-Neyman, S., 1993: Badania wybranych właściwości drewna sosny zwyczajnej (Pinus sylvestris L.) na tle klas biologicznych w drzewostanie. (Studies on selected properties of Scots pine (Pinus sylvestris L.) wood in view of tree biosocial position in the stand). Folia Forestalia Polonica (Ser. B) 24: 133-145.

37. Poorter, H., Niklas, K.J., Reich, P.B., Oleksyn, J., Poot, P., Mommer, L., 2012: Biomass allocation to leaves, stems and roots: meta-analyses of interspecific variation and environmental control. New Phytologist 193(1): 30-50.

38. Poorter, H., Sack, L., 2012: Pitfalls and possibilities in the analysis of biomass allocation patterns in plants. Frontiers in Plant Science 3(259): 1-10. Shininger, T.L., 1979: The control of vascular development. Annual Review of Plant Physiology 30(1): 313-337.

39. Shinozaki, K., Yoda, K., Hozumi, K., Kira, T., 1964a: A quantitative analysis of plant form - the pipe model theory. I. Basic analyses. Japanese Journal of Ecology 14: 97-105. 
40. Shinozaki, K., Yoda, K., Hozumi, K., Kira, T., 1964b: A quantitative analysis of plant form the pipe model theory. II. Further evidence of the theory and its application in forest ecology. Japanese Journal of Ecology 14: 133-139.

41. Shmulsky, R., Jones, D.P., 2011: Forest products and wood science: An introduction. 6th ed. Pp 426-433, Wiley-Blackwell. West Sussex, UK.

42. Sowiński, P., Szczepaniak, J., 2015: Transport dalekodystansowy u roślin: szlaki, mechanizmy, ewolucja (Long-distance transport in plants: paths, mechanisms, and evolution). Kosmos 64(3): 457-469.

43. Steudle, E., 1994: Water transport across roots. Plant Soil 167(1): 79-90.

44. Sudachkova, N.E., Milyutina, I.L., Romanova, L.I., 2012: Biochemical adaptation of conifers to stressful conditions of Siberia. Pp 98-175, Acad. Publ. House "GEO". Novosibirsk, Russia.

45. Tomaszewski, M., 1964: The mechanism of synergistic effects between auxin and some natural phenolic substances. In: Régulateurs Naturels de la Croissance Végétale. Pp 335-351, Coll. Intern. C.N.R.S. Paris.

46. Tsuyama, T., Takabe, K., 2014: Distribution of lignin and lignin precursors in differentiating xylem of Japanese cypress and poplar. Journal of Wood Science 60(5): 353-361.

47. Üner, B., Karaman, I., Tanriverdi, H., Özdemir, D., 2011: Determination of lignin and extractive content of Turkish Pine (Pinus brutia Ten.) trees using near infrared spectroscopy and multivariate calibration. Wood Science and Technology 45(1): 121-134.

48. Van Laar, A., Akça, A., 2007: Forest mensuration. Pp 95-147, Springer. Dordrecht, The Netherlands.

49. Vanninen, P., Mäkelä, A., 2000: Needle and stem wood production in Scots pine (Pinus sylvestris) trees of different age, size and competitive status. Tree Physiology 20(8): 527-533.

50. Vanninen, P., 2004: Allocation of above-ground growth in Pinus sylvestris - impacts of tree size and competition. Silva Fennica 38(2): 155-166. 
Tomasz Jelonek ${ }^{*}$, Witold Pazdrowski, Arkadiusz Tomczak ${ }^{1}$

Poznan University Of Life Sciences

Faculty Of Forestry

Department Of Forest Utilisation

Wojska Polskiego 71A, 60-625 poznan

Poland

*Corresponding author: tomasz.jelonek@up.poznan.pl

JoAnna KopaczyK ${ }^{1,2}$

1Poznan University Of Life Sciences

Faculty Of Forestry

Department Of Forest Utilisation

Wojska Polskiego 71A, 60-625 Poznan

Poland

2Adam Mickiewicz University

Faculty Of Biology

Department Of Plant Ecophysiology

Umultowska 89, 61-614 Poznan

POLAND

Magdalena Arasimowicz-Jelonek

Adam Mickiewicz University

Faculty Of Biology

Department Of Plant Ecophysiology

Umultowska 89, 61-614 Poznan

PolAnd 
